\title{
The use of cues for attention in ancient Greek art: aspects that influence concentration in the work of art and its elements
}

\section{El uso de señales para la atención en el arte Griego antiguo: aspectos que influencian la concentración en la obra de arte y sus elementos}

\author{
Antonio Manuel Duarte \\ Universidade de Lisboa, Faculdade de Psicologia \\ amduarte@fp.ul.pt \\ Manolis I. SteFANAKIS \\ University of the Aegean \\ stefanakis@rhodes.aegean.gr
}

Recibido: 26 de septiembre de 2014

Aprobado: 8 de junio de 2015

\begin{abstract}
The goal of this study is to identify cues for the cognitive process of attention in ancient Greek art, aiming to find confirmation of its possible use by ancient Greek audiences and artists. Evidence of cues that trigger attention's psychological dispositions was searched through content analysis of image reproductions of ancient Greek sculpture and fine vase painting from the archaic to the Hellenistic period - ca. 7 th -1 st cent. BC.

Through this analysis, it was possible to observe the presence of cues that trigger orientation to the work of art (i.e. amplification, contrast, emotional salience, simplification, symmetry), of a cue that triggers a disseminate attention to the parts of the work (i.e. distribution of elements) and of cues that activate selective attention to specific elements in the work of art (i.e. contrast of elements, salient color, central positioning of elements, composition regarding the flow of elements and significant objects).

Results support the universality of those dispositions, probably connected with basic competencies that are hard-wired in the nervous system and in the cognitive processes.

Keywords: attention, ancient Greek art, selective attention, psychology of art.
\end{abstract}

Duarte, A.M., Stefanakis, M. I. (2015): The use of cues for attention in ancient Greek art: aspects that influence concentration in the work of art and its elements. Arte, Individuo y Sociedad, 27(3) 517-535 


\section{Resumen}

El objetivo de este estudio es identificar las señales para el proceso cognitivo de la atención en el arte Griego antiguo, con la intención de detectar su posible uso por los antiguos griegos (público y artistas). La evidencia de señales que desencadenan las disposiciones psicológicas de la atención se buscó mediante el análisis de contenido de reproducciones de imágenes de arte Griego antiguo (escultura y pintura de vasos desde el período arcaico hasta el período Helenístico - ca. $7^{\circ}-1^{\circ}$ siglo AC).

Por medio de este análisis fue posible observar la presencia de señales que condicionan la orientación para la obra de arte (i.e. amplificación, contraste, énfasis emocional, simplificación, simetría), de una señal que provoca una atención diseminada a las partes de la obra (i.e. distribución de los elementos) y de señales que activan una atención selectiva a las partes de la obra (i.e. contraste de los elementos, color saliente, posicionamiento central de los elementos, composición con respecto al fluir de los elementos y objetos significativos).

Los resultados apoyan la universalidad de esas disposiciones, probablemente relacionado con competencias básicas del sistema nervioso y de los procesos cognitivos. Palabras clave: atención, atención selectiva, arte Griego antiguo, psicología del arte.

Summary: 1. Introduction, 2. Method, 3. Results, 3.1. Amplification, 3.2. Contrast, 3.3. Emotional Salience, 3.4.Simplification, 3.5. Symmetry, 3.6. Distribution and Contrast of Elements, Salient Color, 3.7. Central Positioning of Elements, 3.8. Composition Regarding the Flow of Elements, 3.9. Significant Objects, 4. Discussion. References.

\section{Introduction}

Archaeology became interested in how and why art has been possibly created and appreciated by the groups that produced and used it. This interest is mainly oriented to pre-history (Dissanayake, 1992; Lewis-Williams, 2002; Lewis-Williams \& Pearce, 2005; Mithen, 1990, 1996) with few attempts that consider the ancient world period (Gonçalves, Moura, Magalhães \& Chalmers, 2013; Lewis-Williams \& Pearce, 2005). In parallel, Psychology has an old interest on how and why people create and appreciate works of art (Arnheim, 1974, 1986, 1988; Gombrich, 1977; Solso, 1996).

Our approach for this study follows the perspective that art functions in a context that demands psychological "active" creators and spectators (Arnheim, 1986; Gombrich, 1977). To make sense out of a work of art, the spectator needs to actively react to it through mental and behavioral processes. These consist of emotional reactions, behaviors and cognitive operations, which use several "cues" of the work of art in order to "construct" an internal coherent representation, on the basis of the stimulus that constitutes it. Correlatively, the artists' effort is to produce a work of art that contains (or not) the necessary "cues" in order to allow (or not) the spectator to process it for a coherent desirable experience. Therefore, the artist must have an intuitive knowledge on how his or her audience naturally reacts to stimuli and must arrange the work's stimulus in a way that, being cognitively processed, produces an intended experience (Gombrich, 1977). A propos we should note that the term "aesthetics" derives from the ancient Greek aiofóvo $\mu \alpha$ l, which means "to perceive", emphasizing the general sensory experience and reactions that stimuli produce (Feagin, 1999). The thesis here presented is illustrated by a story reported by Ioannes Tzetzes of Byzantium (1110 - 1180 AD), and remembered by Gombrich in his "Art 
and Illusion" (1977), regarding the competition for a high pillar statue of Athena between Phidias and Alcamenes, in the Athens of ancient Greece. While Alcamenes presented a realist figure for the goddess, Phidias exaggerated the features of her face and body, considering the distance from which it would be seen.

"(...) when these two images were afterwards brought to light and compared, Phidias was in great danger to have been stoned by the whole multitude, until the statues where at length set on high. For Alcamenes his sweet and diligent strokes being drowned, and Phidias his disfigured and distorted hardness being vanished by the height of the place, made Alcamenes to be laughed at, and Phidias to be much more esteemed." (Junius 1638, p. 232 - 233 cit. Gombrich, 1977, p. 153-154).

Specifically, artists' control of spectators' reactions involves arranging "cues" directed to their emotions (Vessel, Starr \& Rubin, 2012) and their cognitive processes (Leder, 2013; Leder, Belke, Oeberst \& Augustin, 2004): attention; sensorial processing; perception; comprehension; interpretation. Nevertheless, this separation is more descriptive than concrete since, assuming a "continuity of the mind" (Spivey, 2006), art appreciation would correspond more to a continuum than to a sequence of stages. Each of the mentioned cognitive processes involves mental activity describable in terms of cognitive "dispositions". These are specific ways of reacting to art stimulus, not necessarily consciously for the spectator (or for the artist) and frequently automatic. In this sense, the perspectives of "Extended Mind Theory" and "Material Engagement Theory" also have relevance for the angle of this article. "Extended Mind Theory" emphasizes interaction between mental states and the physical-social environment therefore conceptualizing cognitive processes as interactive networks (that connect brain, body and world) and cultural artifacts as extensions of the cognitive system (Clarck, 2008; Clarck \& Chalmers, 1998). In parallel, "Material Engagement Theory" points that human beings think through the objects they create, that gain then a "cognitive life" (Malafouris \& Renfrew, 2010).

The perspective of art as a "(..) kind of cognitive engineering. (...) an activivity intendend to influence the minds of an audience." considers that art expresses a human propensity for joint and reciprocal control of attention, which is seen as the basis of communication (Donald, 2006, p. 4). It seems then that the control and involvement of attention is an essential basic aspect of the aesthetic encounter, even if besides attention to visual form this encounter presupposes a conception of the work of art "(...) as a thing of a particular kind (...)" (Levinson, 2011, p. 205). Now regarding the cognitive process of attention to the work of art - precisely the focus of this study psychology of art has been identifying a range of correspondent "cues", revised in the next sections: amplification; contrast; emotional salience; simplification; symmetry; distribution of elements; contrast of elements; salient color; central positioning of elements; composition regarding the flow of elements; and significant objects.

First of all, there is a prerequisite for our appreciation of a work of art: it must "catch" our attention by activating a specific significant reaction to it. It has even been defended that art appreciation is motivated by the pleasure provoked by attention arousing (Berlyne, 1971). Now, our nervous system tends to be particularly activated by artistic representations, which not only reproduce the essence of the objects symbolized but actually amplify them, on the form of "super-stimulus" 
that facilitate recognition (Kandel, 2012; Ramachandran, 2011; Ramachandran \& Hirstein, 1999). The amplification involved on exaggerated representations might function as a trigger for the same neurological reactions (located on the limbic system) activated by the original objects that works of art try to represent (Ramachandran \& Hirstein, 1999). Instances of the use of exaggeration in art as a reaction enhancer have been pointed at several levels, like form, color and representations of posture or movement (Ramachandran, 2011; Ramachandran \& Hirstein, 1999). Particularly, intensified reactions to exaggerated representations of the face (Freiwald, Tsao \& Livingstone, 2009) have been attributed to a supposed connection between cerebral areas that process it and a cerebral region (i.e. the amygdale) which is important for the integration of emotions, dispositions and social reinforcement (Kandel, 2012). In parallel, intensified reactions to representations of exaggerated postures have been ascribed to a possible hyper-activation of "mirror neurons" that "fire" both during an action execution and its observation (Ramachandran, 2011). Besides, the attention to exaggerated artistic representations might be grounded in a type of reaction with a probable adaptive value, considering its importance in the detection of colored fruits hidden in foliage and the recognizance of faces (Ramachandran, 2003; Solso, 2003). Furthermore, there is functionality on the progressive amplification of forms within a style, along with the change of styles, in maintaining the reaction to works of art which, without variation, would lead to habituation and insensibility (Martindale, 1990).

Another attention attractor to a work of art is contrast, meaning a difference between two adjacent areas regarding a property (e.g. luminescence, color, texture, deepness, content), which might also derive from primates' functional competence to discriminate fruits from general natural context (Ramachandran, 2011).

Besides frequently provoking our attention by exaggeration and contrast, works of art also seldom draw attention due to the emotional salience of their elements, connected to their evaluation as beautiful (Chatterjee, 2013) or to metaphoric elicited associations (Levy, 2012). As Damasio (2010) states, emotions can affect the cognitive processing, like the possible influence of joy in the acceleration of thinking and in the reducing of attention to unrelated events.

Despite the fact that amplification, contrast and emotional salience in the work of art tend to seize our attention to it, simplified non-redundant representations can also exert the same effect, since they help us not to distract our limited attention resources to the essential attributes of the represented object (Ramachandran \& Hirstein, 1999).

Symmetry in the work of art can also act as an attention trigger, a fact possibly connected to the symmetry of many biologically significant objects (e.g. predator, prey; mate) which (pre)humans gained detecting in the midst of many non-symmetric vegetal and material objects (Ramachandran, 2011; Ramachandran \& Seckel, 2012). Relevant here is the contribution of many artists to the enterprise of military camouflage as a form of visual protection (Behrens, 2002, 2009). Besides, symmetry is also unconsciously known as an indication of health, since symmetry of the face is a sign of it (Ramachandran, 2011).

Once a work of visual art "catches" a spectator's attention he or she scans it in a certain way. Scanning starts with an initial distributed attention, which involves 
a dissemination of gaze ("scanpath") with short eye fixations intervals (Stark \& Ellis, 198). This "scanpath" allows a general vision of the work and is normally followed by a subsequent selective attention, consisting of longer gaze fixations, that allow gathering of specific or relevant information (Yarbus, 1967; Locher \& Nodine, 1987; Shimamura, 2013; Starr, 2013), while also reflects the limitations in processing information (Mather, 2014). Selective attention acts in the direction of areas considered to be "rich in information" (Molnar, 1981), normally at the image's "center" (Quiroga \& Pedreira, 2011), of salient color and of greater contrast (e.g. contrast of light or color) (Quiroga \& C. Pedreira, 2011). As a matter of fact, attention to the elements of a work of art is influenced by their degree of gestaltic integration on their context's remaining elements (Nodine \& Kundel, 1997). In this way, contrast between an element and its context will enhance its discrimination, increasing the probability of audience's attention to it. During scanning the eyes move in small rapid jerky ("saccadic") movements, giving the impression of an instant image apprehension. Nevertheless, a conscious processing of what is seen only happens during fixation moments between saccades, of few milliseconds (Kandel, 2012). Eye movements permit an efficient image exploration by the retina central area (the "fovea"), the only one that allows a distinct vision, and prevents image fading, that happens when the eyes fix in one direction (Kandel, 2012; Nodine \& Kundel, 1997). Moreover, decisions on the eyes' movements seem grounded on an hypothesis testing process about the nature of the represented objects, in a trade between eyes and brain where those are directed to search information that confirm or refute the assumption on what was seen (Kandel, 2012).

In the same way, it was proposed that one of the most important factors of attention's orientation to the elements of a work of art is its "centers": more or less explicit areas with bigger compositional weight that, acting as sources of "perceptual energy", would attract our attention (Arnheim, 1974, 1986, 1988). These "centers" are seen as interacting between themselves, creating "actions vectors" that converge to each other and to the frameworks (Arnheim, 1974, 1986, 1988). Nevertheless, it is considered that, in some cases, the "center" is not explicit, being "virtual", as created by the interaction of several vectors (Arnheim, 1989 cit. Verstegen, 2005).

Moreover, considering that the attention pattern to a work of visual art is influenced by the composition regarding the flow of its elements (e.g. a vertical alignment of elements conditions a vertical movement of the eyes) (Quiroga \& Pedreira, 2011), we can conceptualize that an organized composition acts as a cue for a non-erratic attention pattern.

The themes or ideas of a work of art are also an influential factor of the attention to its parts (Zaidel, 2013). Specifically, the representations of certain objects, with an emphasis to the human body and its parts, specially the face, have a special power to catch attention, due to the existence of visual cortex areas specialized on their processing (i.e. the "extratiate body area" and the "fusiform face area - FFA") (Mather, 2014; Ramachandran, 2003; Solso, 2003; Tong Nakayama, Moscovitch, Weinrib, \& Kanwisher, 2000). As reminded by Kandel (2012) the face it's the object to which the brain concedes the biggest recognition area. Sensibility to the body and particularly to the face has important adaptation significance, due to its informative 
value regarding identity and psychological state of others (Solso, 2003). Besides, human attention to represented faces tends to involve a particular focus on the eyes (Solso, 2003) and on their orientation (the cortex might have a specialization for this in the "superior temporal sulcus") (Kandel, 2012), due to the eyes' importance as a source of information on others and as a platform for communication (Solso, 2003; Kandel, 2012). Moreover, characters' eyes orientations influence how a spectator orients its own look to specific parts of the work of art, a phenomena that might be related to the supposed specialization of the cortex (in the "superior temporal sulcus") in processing an interlocutor's gaze, which is functional in the determination of his intentions and will to communicate (Kandel, 2012). Finally, character's emotional expressions of fear or anxiety might act as a factor of attention to the work of art and its elements, since some studies observed that facial expressions of fear tend to activate us and to increase our acquisition of sensorial information (Kandel, 2012).

There are implicit suggestions of ancient Greek audience's and artists' use of some psychological dispositions in the literature (Gombrich , 1977; Spivey, 2006), but we are not aware of empiric studies that address this question in a more systematic way. Our choice of ancient Greek art as the vehicle for exploring this issue relates with the role of the "Greek Revolution" (Gombrich , 1977) in building the matrix of Western World's creation and appreciation of art.

The research question of this study is whether in ancient Greek art there are signs of the cues that trigger the psychological dispositions implicated in attention to visual art appreciation, and that therefore might testify for both the use of these dispositions by ancient Greek audiences, and the knowledge of them by ancient Greek visual artists. The goal is then to identify in ancient Greek fine painted pottery and sculpture (from the archaic to the Hellenistic period - ca. 7th -1st cent. BC), the presence of cues that trigger orientation to the work of art (i.e. amplification, contrast, emotional salience, simplification, symmetry), of a cue that triggers a disseminate attention to the parts of the work (i.e. distribution of elements) and of cues that activate selective attention to specific elements in the work of art (i.e. contrast of elements, salient color, central positioning of elements, composition regarding the flow of elements and significant objects). Possible presence of such cues will strengthen the notion of the universality of their correspondent attention dispositions.

\section{Method}

To find evidence that could answer the research question we applied principles of the "content analysis" research technique (Miles \& Huberman, 2013) in analyzing ancient Greek pieces' image reproductions of fine painted pottery and sculpture (from the archaic to the Hellenistic period - ca. 7th -1st cent. BC). We first listed the main cognitive dispositions corresponding to the attention processes involved in art appreciation, along with the cues (categories) that might activate those dispositions, on the basis of the literature review on the psychology of attention to visual arts presented in the Introduction (Table 1). 


\begin{tabular}{l|l}
\hline$\underline{\text { Attention Dispositions }}$ & Activating Cues \\
\hline Orientation to the work of art & $\begin{array}{l}\text { Amplification } \\
\text { Contrast } \\
\text { Emotional salience } \\
\text { Simplification } \\
\text { Symmetry }\end{array}$ \\
\hline Disseminate attention to parts & Distribution of elements \\
\hline Selective attention to parts & $\begin{array}{l}\text { Central positioning of elements } \\
\text { Salient color of elements } \\
\text { Contrast of elements } \\
\text { Composition regarding the flow of elements } \\
\text { Significant objects }\end{array}$ \\
\hline
\end{tabular}

Table 1. Attention dispositions in art appreciation and corresponding activating cues.

Subsequently to this listing we proceeded with search for cases that contain one or more salient cues that trigger each of those dispositions. Search was based on "document analysis" research methodology (works of art were analyzed as products of human activity) (Duffy, 2005) and "case study" (specific instances of illustrative works of art were selected as units of analysis) (Yin, 1989). The illustrative cases were identified by the first author (a psychologist with background on Psychology of Art) on the basis of an analysis of a random sample of ancient Greek works of art's reproductions, accessed by "screening" specialized sources of ancient Greek works of art (books and Internet sources). The "screening" strategy of images was deductive, consisting in the images' analysis by trying to locate positive cases with presence of one or more of the cues listed in table 1 . Once positive cases were identified, they were subject to the analysis of the second author (an archeologist with background on Classical Greek Archeology), of an analyst with background on the visual arts and of another with background on linguistics, in order to have a confirmation of them as representative cases (i.e. works with presence of the supposedly present cues). Cases that were not corroborated by all analysts were dismissed and substituted by other cases, then subjected to the same confirmation procedure.

In order to concretize and clarify the use of such methodology of analysis, an example of its appliance is given to one of the selected sources - the illustrated monography titled "Greek Art", by Siebler (2007): each of the book's reproductions of works of art was attentively checked regarding the possible presence of one or more of the eleven cues listed in table 1; all works found of containing one or more of these cues (as it was considered to happen in the amphora attributed to Exekias, of Achilles and Ajax, presented here in Fig. 6, regarding the cues of "central position of elements" and "composition regarding the flow of elements") were listed and assembled with equivalent woks from other sources; from this list the work considered to be the best illustrative on the presence of the correspondent cues was selected (i.e. the amphora referred above), in order to be analyzed by the three other mentioned 
analysts, in terms of possible presence or not of those same cues; if all analysts would corroborate the presence of the same cues (as it happened with the same amphora) the work would be considered has an evidence of the use of such cues.

\section{Results}

This section presents elements, detected in ancient Greek works of art, that constitute evidence of cues triggering cognitive dispositions involved in the attention process that is implicated in art appreciation. These cues testify the possibility that ancient Greek audiences were appreciating works of visual art on the basis of certain universal cognitive dispositions, from which ancient Greek artists would already have a degree of knowledge.

\subsection{Amplification}

Which signs of possible deliberate use of exaggeration can we find already in ancient Greek art, which might have performed the role of catching audiences' attention? Regarding the use of exaggeration of size an example is presented by the "Farnese (or Weary) Hercules", work of Glykon of Athens (3rd cent. AD) (Naples, Museo Archeologico Nazionale, coll. Farnese 6001), a massive marble statue copy of a prototype by Lysippus, originally cast in bronze in the late 4th century BC (Fig. 1).

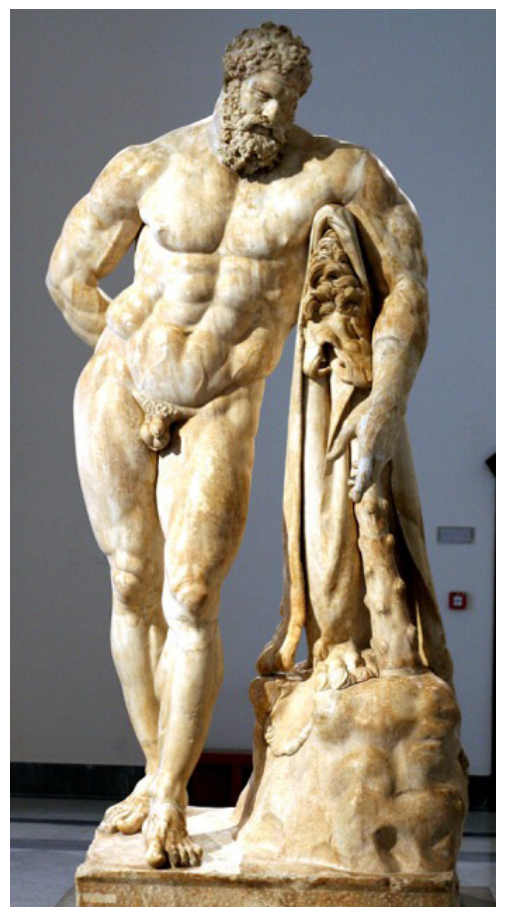

Figure 1. Glykon of Athens, Farnese Hercules, $3^{\text {rd }}$ cent. AD (copy of a late $4^{\text {th }}$ cent. BC sculpture of Lysippus). (http://commons.wikimedia.org/wiki/File:Herakles_Farnese_MAN_Napoli_Inv6001_n01.jpg). 
This sculpture catches our eye mainly due to the heroic scale of Hercules, with its heavy, dramatically pumped musculature, exaggerated with the help of the play of light and shadows (for references on this work see: Haskell and Penny, 1981; Vermeule, 1975). It is a work that planted the seeds for the so-called "baroque" style in Hellenistic sculpture, with breathtaking monumental works, full of theatricality, pathos, strength and magnitude (for a reference on this style see: Pollitt, 1986). The relatively small head of Hercules, and of the remains of the lion where he supports his armpit, in comparision with the rest of his body, probably also contribute to the perception of a body of exagerated size. This case, of the use of exageration of size in ancient Greek art, goes in the line of the reference of Spivey (2006) to the so called "Riace Bronzes", by Polycletus (460 - 430 BC), that represent two man with harmonious but evidently exagerated bodies (for a reference on this work see: Muzzupappa et al. (2012)).

Besides, exaggeration of color and brightness happens, in ancient Greek art, in most of the figures on red-figure (black background) vases of the archaic and classical periods, that so "gain" an amplified tone of color or brightness, therefore catching so well the audience's attention (for references on the red-figure technique see: Boardman, 1989, 2000; Moore, 1997; Stefanakis, 2013). As an example here, we point the medallion in the inside of a red-figure kylix, by Sosias (early $5^{\text {th }}$ century BC) (Berlin, Antikensammlung, F2278), where Achilles is nursing the injured Patroclus (Fig. 2).

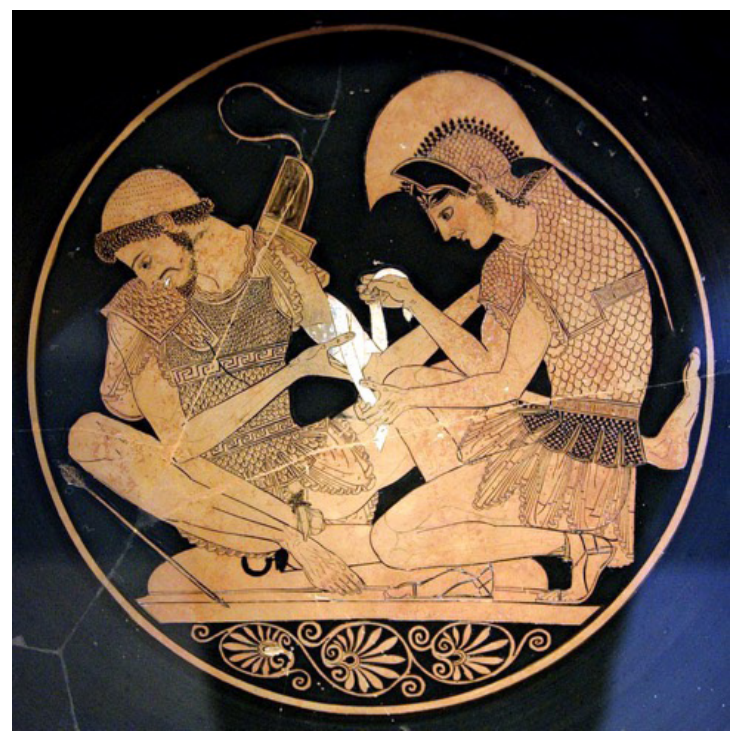

Figure 2. Sosias, Red-figure kylix, early $5^{\text {th }}$ cent. BC.

(http://commons.wikimedia.org/wiki/File:Akhilleus_Patroklos_Antikensammlung_Berlin_F2278.jpg).

The reddish clay color of the figures, against the black background, works as a spot-light to "light up" the scene. Moreover, the action -the banding up of Patroclus arm- is emphasized by the white color of the bandage, not to mention the white of 
Patroclos's teeth (for a reference on this work see: CVA online n.200108). Imagining that the color of the figures wouldn't be perceived as so intense, something that probably is also related with the contrast with the blackness of the background, we could expect that the work would possibly not catch so much attention. Recent revelation of fluorescent pigment traces in ancient Greek sculptures, on the basis of ultraviolet light analysis (Brinkmann, Primavesi \& Hollein, 2010; Panzanelli, Schmidt \& Lapatin, 2008), also consolidates the hypothesis of the use of the referred cue for attention on the focused artistic context.

Regarding the triggering of attention by exaggeration of posture, this can be observed, in ancient Greek Art, in the statue known as the "Laocoön Group", possibly created between $27 \mathrm{BC}$ and $68 \mathrm{AD}$ (Vatican, Vatican Museums, 1059), by three Rhodian sculptors - Athanadoros, Hagesander and Polydoros (Fig. 3).

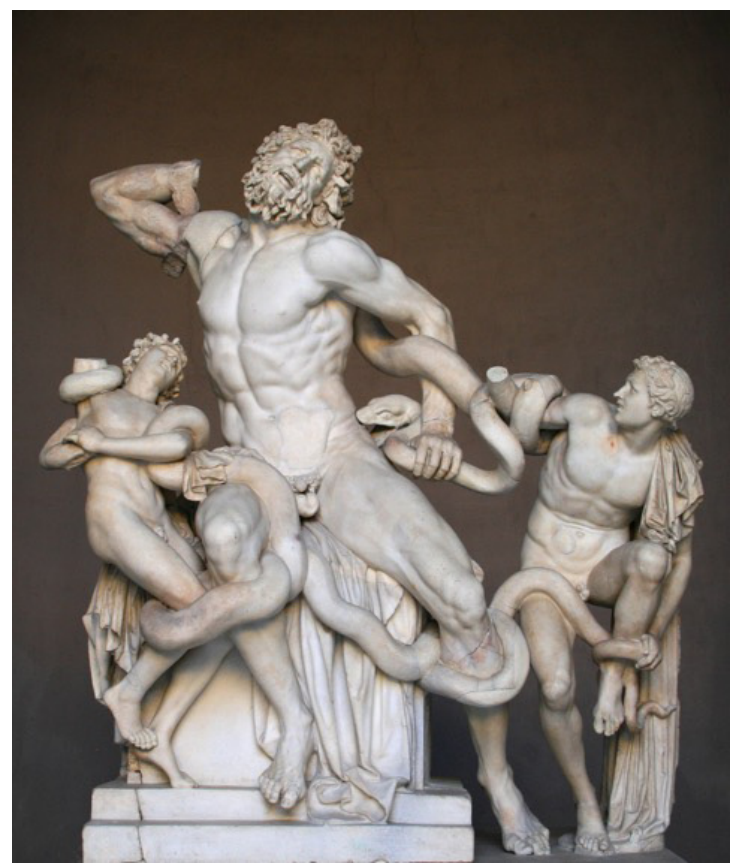

Figure 3.Athanadoros, Hagesander and Polydoros, Laocoön Group, 27 BC - 68 AD. (http://commons. wikimedia.org/wiki/File:0_Laocoon_Group_-_Museo_Pro_Clementino_(Vatican).jpg).

The dramatic figure of Laocoön and his sons, exhibiting the extreme postures of humans struggling with two serpents that embrace them, inevitably catches our attention. The probable "empathy" with the characters postures possibly activate attention to the work, since it might promote the internal simulation of a posture of struggle (the central figure of the father, that tries to avoid the snake's bite), of a posture of defeat (the left figure of the son, that seems already under the effect of the snake') bite), and also of a posture of horror (the right figure of the son, that looks in shock by what he witnesses) (for references on this work see: Buranelli Liverani \& Nesselrath, 2006; Seymour, 1989; Stewart, 1977). 
Regarding the presence of triggers of attention in Greek ancient art due to amplification of movement, we point out the so-called statue of the "Artemision jockey", by an unknown artist (150-146 BC) (Athens, National Archaeological Museum, 15177) (Fig. 4).

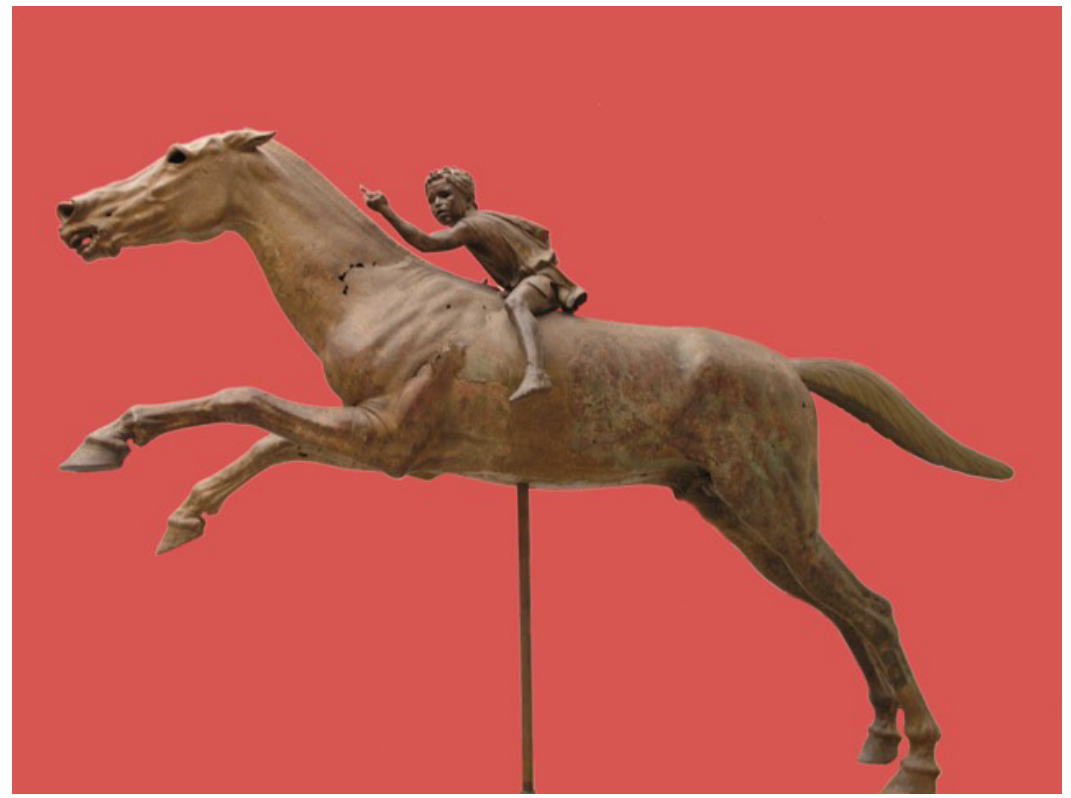

Figure 4. Unknown artist, Artemision jockey, 150 - 146 BC.

(http://upload.wikimedia.org/wikipedia/commons/3/32/NAMA_Jockey_Art\%C3\%A9mision.jpg).

The broad movement of the approximately life-size racehorse, along the pronounced inclination and gesture of its disproportionate young rider, are probable factors that contribute to captivate audience's attention to the sculpture. As a matter of fact, the horse seems to be represented as displaying the exaggerated movements required by a speedy run, which can be perceived on the basis of its posture, stretched musculature and head expression. Besides, the rider' movements are also exaggerated, due to his front inclination and arm gesture (for a reference on this work see: Hemingway, 2004).

\subsection{Contrast}

In ancient Greek art, the use of the color contrast cue is clearly present in the already mentioned figures on red-figure (black background) vases. Moreover, the use of this same cue is also present on the earlier black figure (red background) vases, used from early $7^{\text {th }}$ to late $6^{\text {th }}$ century $\mathrm{BC}$ (and sporadically thereafter), as observed in a black-figure kylix from Vulci, by Exekias, from ca. 530 BC (Munich, Antikensammlungen, 2044) (Fig. 5) (for references on the black-figure technique see: Beazley, 1986; Boardman, 1991; Hatzivassiliou, 2010). 


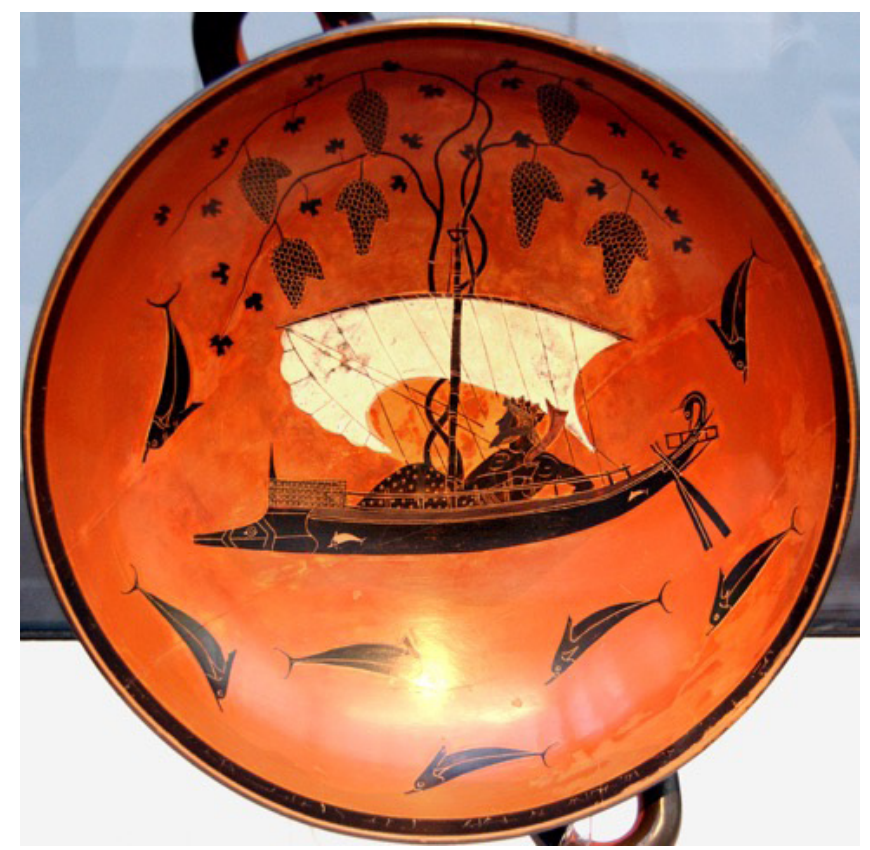

Figure 5. Exekias, Black-figure kylix from Vulci, ca. 530 BC. (http://commons.wikimedia.org/wiki/ File:Exekias_Dionysos_Staatliche_Antikensammlungen_2044_n2.jpg).

The contrast between the red background and the blackness of the depicted ship, of the figure of Dionysus that sails it, of the vines and grapes that grow from its mast and of the dolphins that surround it concur for the attention to the work. Furthermore, attention is also promoted by the contrast between the white sail, the red background and the black figures (for a reference on this work see: CVA online n.310403).

\subsection{Emotional Salience}

An instance of the use of this cue in ancient Greek art can be observed in the previous mentioned sculpture of the "Laocoön Group", by Athanadoros, Hagesander and Polydoros, from 27 BC-68 AD (Vatican, Vatican Museums, 1059 - Fig. 3). As a matter of fact, this work seizes us also due to the awfulness of the depicted situation, increased by the expression of pain and horror of the central figure of the Trojan priest, struggling with the serpents that embrace him, near a son already agonizing with poison and another that looks at him in horror.

\subsection{Simplification}

This "less is more" effect on attention can be observed, in ancient Greek art, in the simple contour line drawings of vases like the "Kalyx Krater from Orvieto", of the Niobid Painter, from the second quarter of the $5^{\text {th }}$ cent. BC (Paris, Musée du Louvre, G 431- public image in: 
http://www.gettyimages.pt/detail/foto/calyx-krater-depicting-apollo-and-hissister-fotografia-de-stock/479642855).

The simple light lines under the figure's feet or bodies create the notion of an outdoor mountainous surface, combined with the simplified depiction of what is perceived as a tree on top of this mountainous area. Besides the contrast of red figures against a black background and representation of broad movements, the work mobilizes attention through the schematic representation of the bodies (for references on this work see: CVA online n.206954).

\subsection{Symmetry}

The use, in ancient Greek art, of symmetry as a possible cue for attention, can be illustrated by design patterns like the one exhibited on an ancient Greek Rhodian plate of the so called "wild goat" style (600-550 BC), where large co-centric zones in the interior of the plate are symmetrically decorated with groups of radiating lines and various geometric signs (Rhodes, Archaeological Museum of Rhodes - public image in: http://it.wikipedia.org/wiki/Stile_delle_capre_selvatiche\#mediaviewer/ File:Geometric_design_rhodian_plate.jpg) (for references on the "wild goat" style see: Cook and Dupont, 2003; Stefanakis, 2012). The symmetry of the co-centric pattern depicted in this plate seems to attract the attention like a kind of "visual magnet".

\subsection{Distribution and Contrast of Elements, Salient Color}

Use of composition in ancient Greek works of art, might be already not independent from a knowledge (even if intuitive and not conscious) of the way audience's attention functions. For example, in the black figure kylix from Vulci, painted by Exekias ca. $530 \mathrm{BC}$, where we see a maritime scene, the supposedly more informative element, a sailing boat driven by Dionysos, is depicted at the center, surrounded by less informative elements that consist of dolphins, vines and grapes (Munich, Antikensammlungen, 2044 - Fig. 5).

Besides, the use of contrast and salient color as a way of leading selective attention to an element in an work of art might be exemplified by the representation on a prize amphora of the Panathenaic Games, by the Marsyas painter (340-339 BC) (Malibu, Getty Villa, 79.AE.147 - public image in: http://commons.wikimedia.org/wiki/ File:Apobates_race_-_Getty_Villa_Collection.jpg).

The figure of the bearded charioteer probably catches more our attention, due to the contrasting salient color of his white clothes, than the black figure of the "apobates", which stands behind him (for a reference on this work see: Valavanis, 2004).

\subsection{Central Positioning of Elements}

Induction of attention to a "center" of the work of art seems well exemplified, in ancient Greek art, by representations like the one on a black figure amphora from Vulci, attributed to Exekias (ca. 550-530/25 BC) (Vatican, Museo Gregoriano Etrusco Vaticano, 344), of Achilles and Ajax playing checkers: both warriors are depicted in 
profile, symmetrically bended in direction of a central bench, where supposedly the game pieces are being moved and to which our attention is probably attracted (Fig.6) (for a reference on this work see: CVA online n.310395).

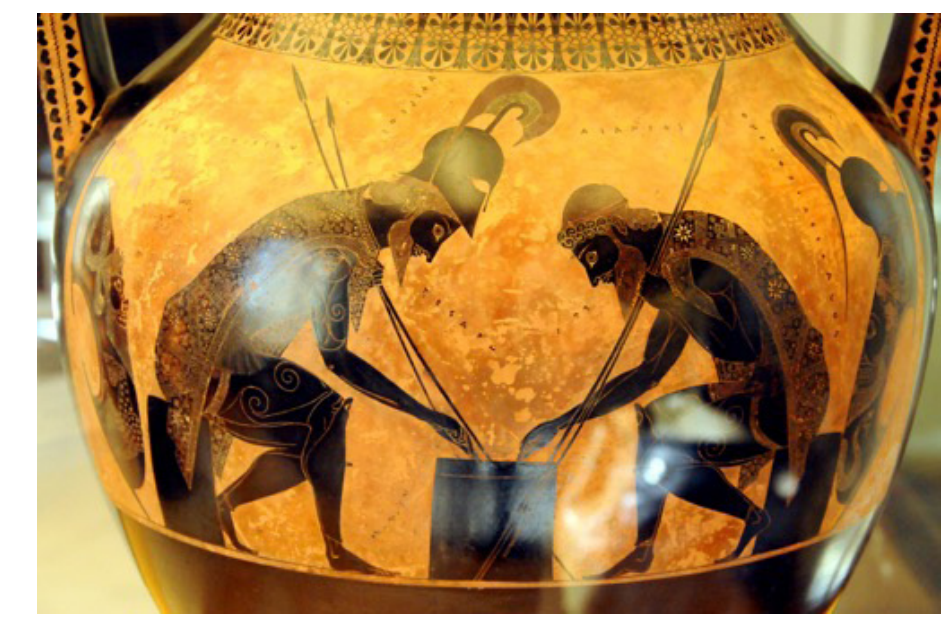

Figure 6. Exekias, Amphora from Vulci, ca. 550-530/25 BC.

(http://commons.wikimedia.org/wiki/File:Akhilleus_Aias_MGEt_16757.jpg).

Moreover, the use of a "virtual center" might also be testified, in ancient Greek art, in body statues like the fighting Gaul from Delos, attributed to Agasias (c.100 $\mathrm{BC})$, that lacking an explicit center, create a "virtual" one through the interaction of the several limbs (Athens, National Archaeological Museum, 247 - public image in: http://commons.wikimedia.org/wiki/File:Statue_of_a_fighting_Gaul_NAMA_247_ (DerHexer).JPG) (for a reference on this work see: $\bar{P}$ icard, 1932).

\subsection{Composition Regarding the Flow of Elements}

The use of this cue, as a way of controlling audiences 'attention to the work's elements, might be testified, in ancient Greek art, on the triangular organizing composition of the already referred vase painting of Achilles and Ajax playing checkers (Vatican, Museo Gregoriano Etrusco Vaticano, 344 - Fig. 6). As a matter of fact, besides the bending of the two warriors in the direction of the checkers', the suspended crossed spears are oriented to the bench where these supposedly stand, probably conditioning a selective attention to it.

\subsection{Significant Objects}

The recurrence of the body thematic in ancient Greek art, as testified by all the examples here presented, is not independent of the power of the human body, specially the face and the eyes, as a significant object that acts as an attention factor. This can be observed on a kylix by the Penthesilea Painter (ca 460-425 BC), where, in the tondo, Achilles is killing the Amazon Penthesilea, who collapses before him, trying to hug him with her left hand while looking him in the eyes, a gaze that might have ignited the love that struck Achilles at the moment of her last breath (Munich, 
Antikensammlungen, 8705 - public image in: http://commons.wikimedia.org/wiki/ File:Akhilleus_Penthesileia_Staatliche_Antikensammlungen_2688.jpg?uselang=it).

Also, the enlargement of the eyes of the two main characters and the clear depiction of the orientation of their gazes, that along facial expression and body posture so well help to decode affection and despair, suggests the intentional use of this cue in ancient Greek art (for a reference on this work see: CVA online n.211565).

\section{Discussion}

Results suggest evidence, in ancient Greek visual art, of all the cues that trigger psychological dispositions involved on attention to visual art. Namely: amplification (of form, color, posture and movement); contrast; emotional salience; simplification; symmetry; distribution and contrast of elements; salient color; central positioning of elements; composition regarding the flow of elements; and significant objects.

We can therefore first conclude the presence of signs, in ancient Greek visual art, that testify on the possible use, by ancient Greek audiences, of the all the cognitive dispositions involved in attention to visual art. Secondly, we can conclude that the same signs possibly indicate an intuitive awareness of these cognitive dispositions by ancient Greek visual artists.

Results can be interpreted in the sense of endorsing the notion of a universal tendency of the cognitive dispositions implicated in the considered process of art appreciation. Results can also be interpreted as signifying that the universality of those basic cognitive dispositions is correlative with a tendency of universality of their (intuitive) knowledge by the artists. As a matter of fact, we suspect it's possible to spot most of the mentioned cues long before ancient Greek art (e.g. use of "superstimulus" in the pre-historic Venus, as pointed by Ramachandran and Histein (1999)). This universality might be explainable by the fact that the mentioned cognitive dispositions are very fundamental, due to basic competencies that are hard-wired both in the brain and the cognitive system of all human beings. But despite the fact we are inclined to this hypothesis as an explanation for the gathered evidence, we have to admit the possibility of other factors. Art is neither created, nor appreciated out of a historical and cultural context and without constrains responsible for important factors like aesthetic canons or style. For instance, cultural referents might influence attention orientation involved in art appreciation, as suggested by research which detected that individuals from different cultures tend to exhibit different attention patterns when viewing photographic images (Chua, Boland \& Nisbett, 2005). But probably, even these constrains are not immune (and might in some extent even reflect) to human beings' natural cognitive dispositions. Another limitation of this analysis relates to the fact that we are considering works of art that are materially transformed due to the passage of time. Besides, we shouldn't forget that parallel to psychological factors, there are others which are involved in the choices of any artist. As always, but more in this case, conclusions must be then considered as an informed approximation.

It would be interesting to go further in this kind of analysis, and to apply it to sensorial processing and more upper-level cognitive dispositions and processes like perception; comprehension; interpretation and emotion. 


\section{References}

Arnheim, R. (1974). Art and visual perception: a psychology of the creative eye. Berkeley and Los Angeles: University of California Press.

Arnheim, R. (1986). New essays on the psychology of art: Berkeley and Los Angeles: University of California Press.

Arnheim, R. (1988). The power of the center: A study of composition in the visual arts. Berkeley and Los Angeles: University of California Press.

Beazley, J.D. (1986). The development of the attic black-figure (Revised ed.). Berkeley: University of California Press

Behrens, R. (2002). False colors: art, design and modern camouflage. Iowa: Bobolink Books

Behrens, R. (2009). Camoupedia: A compendium of research on art, architecture and camouflage. Iowa: Bobolink Books

Berlyne, D. (1971). Aesthetics and psychobiology. New York: Appleton-CenturyCrofts

Boardman, J. (1989). Athenian red-figure vases: The archaic period. London: Thames and Hudson

Boardman, J. (1991). Athenian black-figure vases. London: Thames and Hudson.

Boardman, J. (2000). Athenian red-figure vases: The archaic period. London: Thames and Hudson

Brinkmann, V., Primavesi, O. \& Hollein, M. (2010). Circumlitio. The polychromy of antique and medieval sculptur. Munich: Hirmer.

Buranelli, F., Liverani, P. \& Nesselrath, A. (Eds.) (2006). Laocoonte. Alle origini dei musei vaticani. Vatican: Museo Vaticano.

Chatterjee, A. (2013). The aesthetic brain - How we evolve to desire beauty and enjoy art. Oxford: Oxford University Press

Chua, H. F., Boland, J. E. \& Nisbett R. E. (2005). Cultural variation in eye movements during scene perception. Proceedings of the National Academy of Sciences of the United States of America, 102, 35, 12.629-12.633. Retrieved from http://www. pnas.org/content/102/35/12629.full.pdf

Clark, A. (2008). Supersizing the mind: embodiment, action and cognition extension. Oxford: Oxford University Press.

Clark, A. \& Chalmers, D. (1998). The extended mind, Analysis, 58, 7-19. doi: http:// dx.doi.org/10.1093/analys/58.1.7

Cook, R. M. \& Dupont, P. (2003). East Greek Pottery. London: Routledge.

CVA online: The Corpus Vasorum Antiquorum Project on line (http://www.beazley. ox.ac.uk/cva/proejectpages/cva1.htm

Dissanayake, E. (1992). Homo aestheticus: Where art comes from and why. New York: Free Press.

Damasio, A. (2010). Self comes to mind - Constructing the conscious brain. New York: Pantheon Books.

Donald, M. (2006). Art and cognitive evolution. In M. Turner (Ed.). The artful mind - Cognitive science and the riddle of human creativity (pp.3-20). Oxford: Oxford University Press. 
Duffy, B. (2005). The analysis of documentary evidences. In J. Bell (Ed.) Doing your research project, (4th ed). (pp.122 -135). Berkshire: Open University Press.

Feagin, S. L. (1999). Aesthetics. In R. Audi (Ed.) The Cambridge dictionary of philosophy (2nd ed.) (pp.11-13). Cambridge: Cambridge University Press.

Freiwald, W. A., Tsao, D.Y. \& Livingstone, M. S. (2009). A face feature space in the macaque temporal lobe. Nature Neuroscience, 12(9), 1187-1196. doi: http:// dx.doi.org/10.1038/nn.2363

Gombrich, E. H. (1977). Art and illusion - A study in the psychology of pictorial representation. Oxford: Phaidon Press.

Gonçalves, A., Moura, J. P., Magalhães, L \& Chalmers, A. (2013). Perceptual images of Conimbriga using High Dynamic Range. Journal of Archaeological Science, 40(1), 116-128. doi: http://dx.doi.org/10.1016/j.jas.2012.06.024

Haskell, F. \& Penny, N. (1981). Taste and the antique: The lure of classical sculpture, 1500-1900. New Haven: Yale University Press

Hatzivassiliou, E. (2010). Athenian black figure iconography between 510 and 475 B.C. (Tübinger Archäologische Forschungen 6). Rahden/Westf.: Verlag Marie Leidorf.

Hemingway, S. (2004). The horse and jockey from Artemision: A bronze equestrian monument of the hellenistic period. Berkeley: University of California Press.

Kandel, E. R. (2012). The age of insight: The quest to understand the unconscious in art, mind, and brain, from Vienna 1900 to the present. New York: Random House

Leder, H. (2013). Next Steps in Neuroaesthetics: Which processes and processing stages to study? Psychology of Aesthetics, Creativity, and the Arts, 7(1), 27-37. doi: http://dx.doi.org/10.1037/a0031585

Leder, H., Belke, B., Oeberst, A. \& Augustin, D. (2004). A model of aesthetic appreciation and aesthetic judgments. British Journal of Psychology, 95, 489508.doi: http://dx.doi.org/10.1348/0007126042369811

Levinsson, J. (2011). Beauty is not one: The irreducible variety of visual beauty. In E. Schellekens \& P. Goldie (Eds.). The aesthetic mind - Philosophy and psychology (pp. 90-207). Oxford: Oxford University Press

Levy, K. (2012). An artistic exploration of inattention blindness. Frontiers in Human Neuroscience, 5, 1-14. doi: http://dx.doi.org/10.3389/fnhum.2011.00174

Lewis-Williams, D. J. (2002). The mind in the cave: Consciousness and the origins of art. London: Thames \& Hudson.

Lewis-Williams, D. J. \& Pearce, D. (2005). Inside the neolithic mind: Consciousness, cosmos and the realm of the gods. London: Thames \& Hudson.

Locher,P. J. \& Nodine, C. F. (1987). Symmetry catches the eye. In J. K. O'Regan \& A. Lévy-Schoen (Eds.) Eye movements: From physiology to cognition (pp. 353361). Holland: Elsevier Science Publications.

Malafouris, L. \& Renfrew, C. (2010). The cognitive life of things: Archaeology, material engagement and the extended mind. In L. Malafouris \& C. Renfrew (Eds.). The cognitive life of things. Recasting the boundaries of the mind (pp. 1-12). Cambridge: McDonald Institute for Archaeological Research, University of Cambridge. 
Martindale, C. (1990). The clockwork muse: The predictability of artistic change. New York: Basic Books.

Mather, G. (2014). The psychology of visual art - Eye, brain and art. Cambridge: Cambridge University Press.

Miles, M. B. \& Huberman, A. M. (1994). Qualitative data analysis: an expanded sourcebook, 2nd ed. California: Sage Publications.

Mithen, S. J (1990) Thoughtful foragers: A study of prehistoric decision making. Cambridge; New York: Cambridge University Press.

Mithen, S. (1996). Prehistory of the mind: A search for the origins of art, religion and science. London and New York: Thames \& Hudson.

Molnar, F. (1981). About the role of visual exploration in aesthetics. In H. I. Day (Ed.) Advances in intrinsic motivation and aesthetics (385-413). New York: Plenum Press

Moore, M.B. (1997). Attic red-figured and white-ground pottery. The Athenian agora $X X X$. Princeton: American School of Classical Studies at Athens.

Muzzupappa, M. A., Gallo, R. M., Mattanò, C., Ruggiero, \& Bruno, F. (2012). a complete morphological study of the right hand of bronzo "A" di Riace. International Journal of Heritage in the Digital Era, 1(1), 55-60.

Nodine, C. F. \& Kundel, H. L (1997). Al Hirschfeld's NINA as a prototype search task for studying perceptual error in radiology. Proc. SPIE 3036, Medical Imaging 1997: Image Perception, 308. doi : http://dx.doi.org/10.1117/12.271306

Panzanelli, R., Schmidt, E. \& Lapatin, K. (Eds.) (2008). The color of life: Polychromy in sculpture from antiquity to the present. Los Angeles: Getty Research Institute

Picard, C. (1932). Le guerrier blessé de l'Agora des Italiens a Délos, Bulletin de Correspondance Hellénique, 56, 491-530. doi: http://dx.doi.org/10.3406/ bch. 1932.2850

Pollitt, J.J. (1986). Art in the hellenistic age. Cambridge: Cambridge University Press.

Quiroga, R. Q. \& Pedreira, C. (2011). How do we see art: An eye-tracker study. Frontiers in Human Neuroscience, 5, 1-9. doi: http://dx.doi.org/10.3389/ fnhum.2011.00098

Ramachandran V. S. (2003). The Emerging Mind. The BBC Reith Lectures. London: BBC and Profile Books.

Ramachandran V. S. (2011). The tell-tale brain - A neuroscientist's quest for what makes us human. New York - London: W. W. Norton \& Company.

Ramachandran, V. S. \& Hirstein, W. (1999). The science of art. A neurological theory of aesthetic experience. Journal of Consciousness Studies, 6(6-7), 15-51.

Ramachandran, V. S. \& Seckel, E. (2012). Neurology of visual aesthetics: Indian nymphs, modern art, and sexy beacks. In A. P. Shimamura \& S. E. Palmer (Eds.). Aesthetic science - Connecting minds, brain and experience (pp. 375-390). Oxford: Oxford University Press.

Seymour, H. (1989). Laocoon rerestored. American Journal of Archaeology, 93(3), $417-422$

Shimamura, A. (2013). Experiencing art: In the brain of the beholder. Oxford: Oxford University Press

Siebler, M. (2007). Greek art. Köln: Taschen 
Solso, R. L. (1996). Cognition and the visual arts. Cambridge: The MIT Press.

Solso, R. L. (2003). The psychology of art and the evolution of the conscious brain. Cambridge: The MIT Press.

Spivey, M. (2006). The continuity of mind. Oxford: Oxford University Press

Spivey, N. (2006). How art made the world: A journey to the origins of human creativity. New York. Basic Books.

Stark, L. W. \& Ellis, S. R. (1981). Scanpath revisited: Cognitive models direct active looking. In D. F. Fisher, R. A. Monty \& J.W. Senders (Eds.) Eye movements: Cognition and visual perception (pp. 193-226). Hillsdale, NJ: Lawrence Erlbaum.

Starr, G. (2013). Feeling beauty - The neuroscience of aesthetic experience. Cambridge: MIT Press.

Stefanakis, M.I. (2012). Introduction in classical archaeology. Basic principles and overview of the ancient greek art (11th-4th c.). Athens: Iamvlichos.

Stewart, A. (1977). To entertain an emperor: Sperlonga, Laokoon and Tiberius at the dinner-table, The Journal of Roman Studies, 67, 76-90. doi: http://dx.doi. org $/ 10.2307 / 299920$

Tong, F., Nakayama, K., Moscovitch, M., Weinrib, O., \& Kanwisher, N. (2000). Response properties of the human fusiform face area. Cognitive Neuropsychology, $17,257-279$.

Verstegen, I. (2005). Arnheim, gestalt and art: a psychological theory. Wien: Springer Valavanis, P. (2004). Games and sanctuaries in ancient Greece - Olympia, Delphi, Isthmia, Nemea, Athens (D. Hardy, Trans.). Los Angeles: Getty Publications.

Vessel, E. A., Starr, G. G. \& Rubin, N. (2012). The brain on art: intense aesthetic experience activates the default mode network. Frontiers in Human Neuroscience, 6, 1-17. doi: http://dx.doi.org/10.3389/fnhum.2012.00066

Vermeule, C. (1975). The weary Herakles of Lysippos, American Journal of Archaeology, 79(4), 323-332. doi: http://dx.doi.org/10.2307/503065

Yarbus, A. L. (1967). Eye movements and vision (B. Haigh, Trans.). New York: Plenum Press.

Yin, R.K. (1989). Case study research - Design and methods, rev. ed. Newsbury Park: Sage Publications.

Zaidel, D. W. (2013). Art and brain: The relationship of biology and evolution to art. In S. Finger, D. W. Zaidel, F. Boller \& J. Bogousslavsky (Eds.). The fine arts, neurology and neuroscience - New discoveries and changing landscapes (pp. 217 -234). Amsterdam: Elsevier. 